\title{
Inovasi Pelayanan Publik Program E-Retribusi Di Dinas Perdagangan Kota Surakarta
}

\author{
Lies Fajarwati Wijaya ${ }^{1}$, Winarti $^{2}$, Joko Suranto ${ }^{3}$ \\ ${ }^{123}$ Program Pasca Sarjana Magister Adminitrasi Publik Universitas Slamet Riyadi Surakarta
}

\begin{abstract}
The e-retribution public service innovation by the Surakarta City Trade Office is a new concept regarding the online levy payment system. First launched in mid-2016, E-retribution as part of the implementation of smart government is included in the smart city indicator. This study uses the typology theory of public service innovation Muluk (2008). Research location in the city trade office Surakarta, with a qualitative descriptive method. The data collection technique was obtained by purposive sampling through informant interviews, observations and documents. The results show that the public service innovation with the e-retribution program can simplifying public services and saving more time, costs and human resources, ensuring accountable transactions. In addition, Eretribution has an impact on increasing Solo Local Revenue every year.
\end{abstract}

Keywords: Innovation, public services, E-Retribution

\begin{abstract}
Abstrak
Inovasi pelayanan publik program e-retribusi oleh Dinas Perdagangan Kota Surakarta adalah konsep baru mengenai sistem pembayaran retribusi secara yang dilakukan secara online. Pertama kali diluncurkan pada pertengahan 2016, E-retribusi sebagai bagian dari pelaksanaan smart government yang termasuk dalam indikator smart city. Penelitian ini menggunakan teori tipologi inovasi pelayanan publik Muluk (2008). Lokasi penelitian di Dinas perdagangan kota Surakarta, dengan metode deskriptif kualitatif. Teknik pengumpulan data diperoleh dengan purposive sampling lewat wawancara infroman, observasi dan dokumen. Hasil penelitian menunjukkan bahwa inovasi pelayanan public dengan program e-retribusi dapat menyederhanakan pelayanan publik dan lebih menghemat waktu, biaya dan sumber daya manusia, terjaminnya transaksi yang akuntabel, Selain itu E-retribusi berdampak pada meningkatnya Pendapatan Asli Daerah Kota Solo setiap tahunnya.
\end{abstract}

Kata kunci: Inovasi, pelayanan publik, E-Retribusi

${ }^{*}$ Penulis Korespondensi

E-mail : winartitik@yahoo.co.id 


\section{PENDAHULUAN}

Tuntutan masyarakat akan pelayanan yang baik, cepat, akurat menuntut aparat pemerintah untuk kreatif dan inovatif. Inovasi berjalan beriringan dengan pekembangan teknologi dunia yang bersifat up to date dan cepat, kemajuan teknologi yang cepat akan mempengaruhi perkembangan kota yang semakin maju. Kondisi ini menjadi faktor pendorong terwujudnya kota pintar atau smart city di sebuah daerah. Masyarakat berharap tata kelola pemerintahan yang baik, termasuk masyarakat Kota Surakarta, yang terus mengikuti perubahan menuju kota cerdas dengan memperkuat pelayanan public. Dengan memanfaatkan kemajuan Teknologi Informasi (IT), kota Surakarta yang dalam hal ini adalah Dinas Perdagangan, mengubah system penarikkan retribusi dengan kebijakan baru yang dikenal dengan istilah "TAPE PASAR" (Teknologi Aplikasi E-Retribusi Pasar). Program eretribusi mulai dilaksanakan pada tahun 2016 dalam bentuk e-money atau smart card yang digunakan para pedagang untuk membayar retribusi dan pada awalnya diberlakukan di empat pasar besar yang ada di Surakarta antara lain, Pasar Gede, Pasar Depok, Pasar Singosaren, dan Pasar Ngudi Rejeki Gilingan pada bulan September tahun 2016. Jumlah pasar tradisional di kota Surakarta ada 44 pasar, yang sudah melaksanakan eretribusi sudah 14 pasar. Menindaklanjuti Peraturan Wali Kota Surakarta No.21/2010 tentang Pendayagunaan Teknologi Informasi dan Komunikasi dalam Penyelenggaraan Pemerintahan, dan pelaksanaannya setelah terbitnya Peraturan Wali Kota No.14/2016 tentang Petunjuk Pelaksanaan Retribusi Pasar; dan Keputusan Walikota Surakarta No.
974/65.2/1/2016 tentang Pelaksanaan Pemungutan Retribusi Pelayanan Pasar dan Retribusi Pelayanan Persampahan/Kebersihan Pada Dinas Pengelolaan Pasar Secara Elektronik. Program e-retribusi merupakan sistem pelayanan publik dalam gerakan reformasi manajemen, yaitu manajemen publik baru yang biasa disebut New Publik Management (NPM). Kettl (2000,5-6), menyatakan bahwa pergerkan reformasi manajemen menampilkan perdebatan tentang governance tentang apa yang harus dilakukan pemerintah ? bagaimana mencapai tujuan sebaikbaiknya ? apa kapasitas yang dibutuhkan untuk bekerja dengan baik ?. Tentunya dalam pelaksanaannya tidaklah pemerintah sendiri, tetapi tidak terlepas dari peran serta masyarakat. Penelitian ini dilakukan dengan tujuan menganalisis inovasi pelayanan publik melalui program eretribusi yang dilakukan di Dinas Perdagangan Kota Surakarta.

\section{METODE PENELITIAN}

Metode wajib ada dalam suatu penelitian, karena dengan metode suatu kegiatan itu dapat digolongkan dalam kegiatan yang sifatnya ilmiah. Metode dalam penelitian ini adalah deskriptif kualitatif dengan teknik penentuan informan secara purposive sampling. Wawancara dilakukan dengan Kepala Dinas, Perdagangan Kota Surakarta, KaBid Pengelolaan Pendapatan, Kepala Pasar/sebagai Ketua Tim, Customer Service Bank yang ada di Pasar, dan Pedagang sebagai pengguna eretribusi. Teknik pengumpulan data dengan cara observasi, wawancara, dan dokumentasi, teknik analisa data dengan menggunakan analisis interaktif dari Miles dan Huberman $(2014 ; 14)$, analisis mulai dari koleksi data, reduksi data, penyajian data, 
verifikasi data dan kondensasi data, yang dalam pelaksanaannya langkahlangkah tersebut merupakan kegiatan analisis yang saling susul menyusul.

\section{HASIL DAN PEMBAHASAN Pelayanan Publik}

Salah satu fungsi negara adalah memberikan pelayanan kepada masyarakat, dengan tujuan meningkatkan kesejahteraan masyarakat. Sedangkan pelayanan prima menjadi tuntutan masyarakat, pelayanan tidak dapat dipisahkan dengan kehidupan seseorang, semakin majunya peradapan masyararakan akan semakin komplek tuntutan masyarakat akan baiknya pelayanan yang diselenggarakan oleh penyelenggara negara. Pelayanan publik diartikan sebagai pemenuhan keinginan dan kebutuhan masyarakat, yang dilakukan oleh penyelenggara negara. Menurut Kurniawan, Pelayanan publik diartikan sebagai pemberian layanan (melayani) keperluaan orang atau masyarakat yang memepunyai kepentingan pada organisasi itu sesuai dengan aturan pokok dan tata cara yang telah ditetapkan (Kurniawan; 2005;4).

Instansi pemerintahan menyelenggarakan pelayanan publik, sesuai dengan kepentingan masyarakat dan bersifat non komersial. Dalam pemerintah melaksanakan tugas pokok dan fungsi, memberikan pelayanan kepada masyarakat umum maupun swasta, ada tiga hal penting yang harus diperhatikan : 1. Masyarakat sebagai warga negara berhak memperoleh pelayanan yang prima; 2. Pemerintah sebagai penyedia layanan; 3. Kepuasan pelanggan (Warni, 2004). Tiga hal tersebut merupakan tujuan yang hendak dicapai dalam pelayanan publik
Pelayanan prima merupakan tuntutan masyarakat kepada penyelenggara layanan, sesuai dengan Undang-Undang Nomor 25 Tahun 2009 Tentang Pelayanan Publik, dengan faktorfaktor seperti keramahan, kredibilitas, akses, penampilan fasilitas, dan kemampuan dalam menyajikan pelayanan. Dalam mewujudkan kepuasan pelayanan kepada masyarakat, dibutuhkan standar pelayanan secara cepat, tepat tanggap dengan biaya murah, sehingga terciptalah suatu pelayanan prima, tentunya pelayanan harus memperhitungkan efisiansi dan efektifitas, dalam kerangka etika pelayanan publik.

Efektifitas pelayanan publik yang dilakukan oleh aparat pemerintah, dapat dilihat dari tingkat keberhasilan pelayanan yang telah diberikan pada publik, yang tentunya harus sesuai dengan tujuan dan sasaran pelayanan publik itu sendiri. Adanya keluhan masyarakat yang berkaitan dengan perilaku para birokrat, merupakan salah satu indikator kualitas pelayanan yang diberikan oleh pemerintah. Pendapat David Osborne dan Ted Gaebler dalam buku Reinventing Government menuliskan tentang pentingnya pelayanan publik oleh birokrasi pemerintah dengan memberi kewenangan kepada pihak swasta untuk berpartisipasi dalam pelayanan publik (dikutip dari Zulkarnaini, 2013: 3-4). Osborne dan Gabler menjelaskan bahwa mewirausahakan birokrasi artinya mentransformasikan semangat wirausaha ke dalam sektor public, sehingga pengelolaan pemerintahan harus kreatif dan inovatif.

Di era otonomi yang nyata dan tanggung jawab, pemerintah dituntut untuk melaksanakan tugas, wewenang dan kewajibannya sesuai dengan peraturan perundang- 
undangan. Dalam urusan pelayanan pemerintah telah membuat Peraturan Pemerintah Republik Indonesia Nomor 65 Tahun 2005 tentang Pedoman Penyusunan dan Standar Pelayanan Minimal, peraturan ini sebagai payung hukum yang berkenaan dengan pelayanan publik, yang yang tentunya disesuaikan situasi dan kondisi masyarakat daerah masing-masing.

\section{Inovasi Pelayanan Publik}

Inovasi sebagai proses atau hasil pengembangan, pemanfaatan dan bisa juga mobilisasi tentang pengetahuan, ketrampilan dan pengalaman untuk menciptakan atau perbaikan sistem baru, yang memberikan nilai yang secara signifikan dan berarti. Inovasi dalam kaitannya dengan pelayanan publik didefinisikan Hurley dan Hult dalam Kusumo (2006:22) mendefinisikan inovasi sebagai mekanisme perusahaan untuk beradaptasi pada lingkungan yang dinamis, maka perusahaan dituntut untuk melakukan pemikiran baru dan menawarkan produk yang inovatif untuk meningkatkan pelayanan dan kepuasan pelanggan. Pendapat lain tentang pelayanan publik datang dari Peter yang dikutip Ferryanto (2009:96) "...Core competencies are different for every organization;... But every organization-not businessesneeds one core competence: INNOVATION".

Banyak pengertian tentang inovasi, namun secara singkat inovasi dapat di artikan, sebagai hasil dari proses pemikiran, gagasan untuk mencapai hasil yang bisa memberikan manfaat, keuntungan dengan tujuan hidup dengan berkelanjutan (sustainanble). Dalam perkembangan jaman, menuntut organisasi publik dalam sebuah lingkup tertentu (negara, lembaga, perusahaan, maupun individu) untuk bisa membuat inovasi, bukan selalu dengan bertahan dengan produk yang sama tetapi bisa membuat produk baru dengan tujuan kesejahteraan masyarakat. Hasil penelitian yang dilakukan oleh Urip Sedyowidodo dan Tri Susanto, menunjukkan bahwa peran manajemen memiliki pengaruh pada pertumbuhan pemikiran kreatif dan perilaku inovatif ( Sedyowidodo \& Susanto; 2013; 380). Menurut Helix yang sering disebut Teori Models menerangkan bahwa suatu inovasi adalah hasil interaksi dari beberapa aktor yang terlibat didalamnya (Praswati, 2017:690), Helix menyebut model ini terdiri dari tiga elemen yang bisa disebut juga sebagai faktor utama yaitu : a. Triple Helix (Inovasi timbul dari kerjasama Universitas, industri dan pemerintah), b. Quadruple Helix (mengelola peran masyarakat sipil dan mempertahankan intekasi elemen TH), c. Quintuple Helix (universitas, industri, pemerintah, masyarakat sipil, dan faktor lingkungan alam yang berguna dalam pembangunan berkelanjutan). Pendapat yang lain, Miles juga berpendapat bahwa konsep inovasi dibidang jasa ada beberapa bagian yaitu : a. Inovasi dalam pelayanan, $b$. Inovasi dalam proses, c. Inovasi dalam perusahaan jasa, organisasi dan industri ( Wawan 2014: 68-69).

Menciptakan model bisnis baru dapat diperoleh ketika mendapatkan keuntungan, kemudian merekayasa ulang dan fokus pada yang baru. Peran teknologi komunikasi dan informasi berhubungan erat dengan pelanggan dan penyedia jasa. Pendapat Rogers dalam bukunya Diffusion of Innovation menjelaskan inovasi adalah sebuah ide, praktek, atau objek yang dianggap baru oleh individu maupun unit adopsi lainnya. Rogers membagi karakteristik inovasi 
diantaranya : a. Keuntungan relatif, b. Kesesuaian, c. Kerumitan, d. Kemungkinan dicoba, e. Kemudahan diamati (LAN 2007:116). Teori difusi inovasi sangat berkaitan dengan ilmu komunikasi utamanya komunikasi massa, karena dalam berbagai situasi efektivitas perubahan berawal dari kebijakan publik kemudian diterapkan oleh masyarakat di luar jangkauan inovasi. Sedangkan menurut Muluk $(2008,45)$, terdapat kriteria atau tipologi inovasi di sektor publik yang digambarkan lewat gambar sebagai berikut :

\section{Gambar 1}

\section{Tipologi Inovasi Pelayanan Publik}

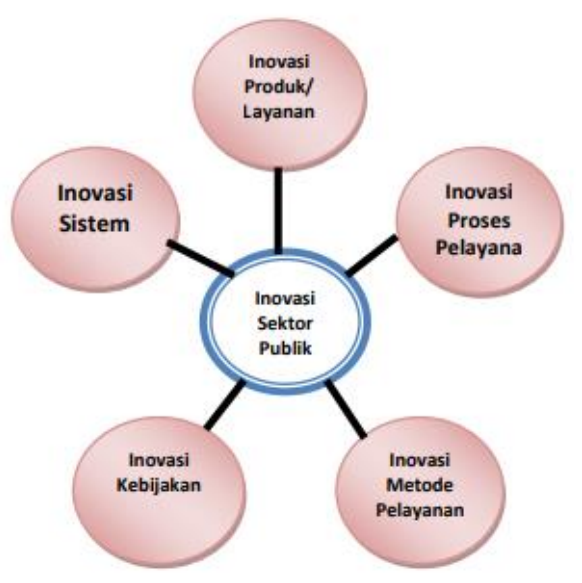

Teori tipologi inovasi pelayanan publik tersebut terdapat empat kreteria, yaitu : a. Inovasi produk atau layanan tergantung perubahan pada bentuk dan desain produk. b. Inovasi proses pelayanan dilihat dari perubahan kualitas yang sifatnya berkelanjutan dan bisa juga kombinasi pada perubahan pada organisasi, prosedur dan kebijakan saat berinovasi. Selain itu dapat diartikan bahwa inovasi proses sebagai upaya peningkatan kualitas proses dari segi internal dan ekternal secara efisien dan sederhana. c. Inovasi metode pelayanan yaitu cara baru dalam memberi pelayanan pada publik. Dari awalnya secara tatap muka, tetapi telah bergeser pada perkembangan teknologi digital. $\mathrm{d}$. Inovasi kebijakan bertumpu pada visi, misi, tujuan dan strategi yang baru. e. Inovasi sistem yakni perkembangan interaksi sistem pada suatu cara baru dalam konteksnya di sektor pemerintahan atau dalam kata lain adanya perubahan dalam tata kelola pemerintahan.

Pendapat yang dikemukakan oleh Muluk sejalan dengan konsep yang dibeberkan oleh Rogers, begitu juga dengan Richard Heeks, dimana peran teknologi begitu kuat untuk membuat inovasi berjalan dengan prosesnya masing-masing. Bicara tentang inovasi tidak bisa lepas dengan teknologi, sehingga orang sudah otomatis bicara tentang inovasi disitulah ada teknologi. Potensi teknologi dalam penerapannya di inovasi, seperti yang dikemukakan oleh Galbraith yang menjelaskan bahwa, produk inovasi merupakan suatu produk sebagai hasil dari proses dari penggunaan teknologi baru, sehingga produk tersebut mempunyai nilai tambah (Lukas dan Ferrel; 200 : 240).

Pemerintah yang tugas utamanya memberikan pelayanan kepada masyarakat dituntut untuk menggunakan terobosan-terobosan baru, ide kreatif yang bersifat original atau bisa juga adaptasi atau modifikasi beberapa metode pelayanan dan melihat dimensi kualitas pelayanan publik (kecepatan, ketepatan, kemudahan, dan keadilan, serta berpedoman dengan prinsip pelayanan publik, sehingga inovasi teknologi dalam hal pelayanan sangat diharapkan masyarakat mendapat kepuasan pelayanan. Tujuan dikeluarkannya Instruksi Presiden 
No. 3 Tahun 2003 Tentang Kebijakan dan Strategi Nasional Pengembangan E-Government, adalah; pengembangan e-government dalam rangka mengembangkan penyelenggaraan kepemerintahan yang berbasis elektronik guna meningkatkan kualitas layanan publik secara efektif dan efisien.

Langkah yang dilakukan Kota Surakarta dalam program e-retribusi salah satunya untuk memperbaiki kualitas pelayanan, selain untuk meningkatkan transparansi dan efisiensi. Dalam rangka meningkatkan pelayanan pemungutan retribusi pasar, Dinas Perdagangan Kota Surakarta memberlakukan sistem pembayaran retribusi secara elektronik, pembayaran melalui aplikasi yang ada di sistem eretribusi. E-retribusi merupakan penarikan secara otomatis dengan layanan berbasis online, sehingga petugas tidak perlu melakukan retribusi secara manual, keliling meminta "iuran" kepada pedagang di pasar satu persatu. Sistem e- retribusi ini selain dapat terjamin transparansi dan efisiensi juga diharapkan dapat mewujudkan kerjasama dengan lembaga-lembaga lain seperti bank.

Penelitian tentang inovasi program e-retribusi dikota Surakarta, memakai teori tipologi inovasi yang dikemukanan oleh Muluk (2008) yaitu inovasi produk/layanan, inovasi proses pelayanan, inovasi metode, dan inovasi sistem. inovasi pelayanan publik program e-retribusi tidak termasuk dalam inovasi kebijakan atau strategi. Jika dilihat inovasi kebijakan/strategi mencakup didalamnya adalah unsur visi, misi, tujuan, dan strategi yang kesemua unsur tersebut adalah baru. Sedangkan pengelolaan retribusi yang dilakukan oleh Pemerintah Daerah termasuk dalam kewajiban Dinas yang bersangkutan dalam menyelenggarakan perencanaan, pengembangan, pengawasan dan evaluasi pasar. Pengelolaan yang dilakukan oleh Dinas adalah memungut retribusi pelayanan pasar sesuai peraturan perundangundangan (Pasal 16 ayat 2C, perda No. I Tahun 2010 tentang Pengelolaan Dan perlindungan Pasar Tradisional).

Untuk menciptakan tata kelola administrasi yang transparan dan akuntabel, strategi pemerintah kota Surakarta dalam hal ini dinas Perdagangan, melakukan pendekatan dalam bidang pelayanan public dengan pendekatan berbasis teknologi informasi. Program eretribusi yang dilakukan oleh dinas Perdagangan kota Surakarta, sesuai teorinya Muluk $(2008 ; 45)$, yang melihat inovasi dalam bidang pelayanan publik dari indikator :

1. Inovasi produk/layanan

Bentuk inovasi produk pelayanan yang diberlakukan kepada pedagang pasar untuk yang dipasar sudah tidak perlu lagi mengunjungi pedagang karena pelayanan dapat membayar retribusi adalah menggunaan kartu e-retribusi yang di desain seperti kartu ATM (berisi saldo nominal dari tabungan yang telah melalui proses top-up oleh pedagang). Pedagang mendapat smart card Mendapat buku tabungan Pembayaran wajib retribusi oleh pedagang sudah menggunakan kartu e-retribusi yang fungsinya sama seperti pembayaran dengan uang tunai. Sedangkan dari segi layanan, petugas penarik retribusi dilakukan secara personal oleh pedagang lewat smart card eretribusi.

2. Inovasi Proses Pelayanan

a. Perubahan Organisasi. Model pelayanan penarikan retribusi 
kepada para pedagang di empat (4) pasar yaitu pasar Gede, pasar Depok, pasar Singosaren, dan pasar Ngudi Rejeki Gilingan dengan sistem eretribusi, membawa perubahan pada organisasi pemerintah. Karena sistem eretribusi, diatur oleh mesin sehingga dengan sistem on-line berpengaruh kepada pengurangan pegawai, informen di dinas Perdagangan menyatakan bahwa; untuk petugas yang awalnya setiap harinya harus mengerahkan minimal 4 orang pagawai/staf setiap pasarnya, sekarang dengan sistem baru hanya mengerahkan 2 (dua) pegawai atau staf yang bertugas di tiap pasar tradisional. Selain megurang jumlah pegawai segingga terjadi efisiensi juga, pegawai/staf dituntut untuk menguasai teknologi, dan pemerintah mau tidak mau memiliki program peningkatan kemampuan pegawai salah satunya penguasaan IT.

b. Kebijakan. E-retribusi Kota Surakarta telah dirancang pada tahun 2010 dengan keluarnya Peraturan Daerah Nomor 1 Tahun $2010 \quad$ Tentang Pengelolaan dan Perlindumgam Pasar Tradisioanal Dengan diberlakukannya e-retribusi, maka pemerintah kota Surakarta segera menyusun kebijakan, langkah ini dilakukan untuk menyusun regulasi/ peraruran sebagai payung hukum dalam pelaksanaan program ini. (Perda, Keputusan Walikota,
MoU dan MoA), jangka waktu pelaksanaan program, Merumuskan SOP, Membangun komitmen dengan pedagangstakeholder-pimpinan dan sebagai. Dan beberapa peraturan perundangundangan seperti, (a) Perwali No. 14 Tahun 2016 Tentang Petunjuk Pelaksanaan Retribusi Pelaayanan Pasar; (b) Keputusan Walikota Surakarta No. 974/65.2/1/2016 TentangPelaksanaan

Pemungutan Retribusi Pelayanan Pasar dan retribusi Pelayanan

Persampahan/Kebersihan Pada Dinas Pengelolaan Pasar Secara Elektronik; (c) MoU dan MoA dengan Pemerintah Kota Surakarta dengan Bank Jateng. Dengan adanya kebijakankebijakan diatas merupakan pedoman dalam pelaksanaan eretribusi di kota Surakarta.

c. Prosedur. Peraturan perundang-undangan, menjadi payung hukum pelaksanaan eretribusi di kota Surakarta, khususnya juklak dan juknisnya. Sebelum diberlakukan Dinas.

d. Peningkatan kualitas strategi mulai dari ditetapkan, mengajak, mencoba, menerapkan, dan mengevaluasi Proses mendiskripsikan bagaimana perubahan dapat terjadi.

Inovasi proses pelayanan terdapat penyatuan aspek pada perubahan di organisasi. Dinas Perdagangan melakukan pengurangan jumlah pegawai, terdapat prosedur pelayanan inovasi. 
Tabel 1

Peningkatan Hasil E-Retribusi

\begin{tabular}{|c|c|c|}
\hline No & Sebelum & Sesudah \\
\hline 1. & $\begin{array}{l}\text { Pembayaran retribusi secara } \\
\text { manual, inefisien }\end{array}$ & $\begin{array}{l}\text { Pembayaran retribusi dengan sistem } \\
\text { eretribusi, efisiensi terwujud }\end{array}$ \\
\hline 2. & $\begin{array}{l}\text { Penarikan oleh petugas pemungut, } \\
\text { tidak semua pedagang yang sudah } \\
\text { membayar retribusi memperoleh } \\
\text { tanda bukti "karcis" sehingga sulit } \\
\text { pertanggungjawabannya } \\
\text { (Transparansi) }\end{array}$ & $\begin{array}{l}\text { Pedagang membayar sendiri, dengan } \\
\text { membuka rekening, pembayaran } \\
\text { retribusi melalui mesin Tapping veader } \\
\text { yang sudah disediakan di pasar-pasar. } \\
\text { Pedagang memperoleh struk bukti } \\
\text { pembayaran transaksi. (transparan). }\end{array}$ \\
\hline 3. & $\begin{array}{l}\text { Tidak banyak pedagang yang } \\
\text { mengenal perbank-an }\end{array}$ & $\begin{array}{l}\text { Peningkatkan pengelaman dan } \\
\text { pengetahuan kepada para pedagang } \\
\text { tentang dunia perbankan }\end{array}$ \\
\hline
\end{tabular}

\section{Inovasi Metode dan Sistem Pelayanan}

Inovasi metode pelayanan adalah cara baru dalam penyelenggaraan pelayanan kepada publik, cara baru yang dimaksud perubahan dari cara konvensional ke elektronik. Dalam pelayanan eretribusi kota Surakarta, memakai metode pelayanan terintegrasi dengan Bank, artinya proses pembayaran dilakukan pedagang dengan cara menabung. Metode pelayanan e-retribusi pasar tradisioal ini dilakukan dengan mudah cukup menempelkan kartu di mesin tap reader kemudian mesin tersebut bisa membaca jumlah saldo yang ada di rekening pedagang. Stakeholder penyedia layanan e-retribusi yaitu pihak perbankan juga sebagai bentuk dari Corporate Social Responsibility perusahaan dalam memberikan produk/layanan.

Kemajuan teknologi sebagai salah satu kebutuhan pokok dalam pelayanan publik agar tercipta pelayanan yang lebih baik (transparan, akuntabel, efisien dan efektif), dengan adanya eretribusi yang diberlakukan bagi pedagang pasar tradisional di kota Surakarta maka, terjadi perubahan tata kelola administrasi pengelolaan retribusi di Dinas Perdagangan Kota Surakarta, pelaporan dilakukan secara realtime sehingga mempermudah pengelolaan retribusi, dan efisiensi penganggaran. Namun pada kenyataannya inovasi eretribusi yang menggunakan sistem elektronik pada dinas Perdagangan Kota Surakata juga mengalami hambatan /kendala, kendala tersebut seperti ; a. Terjadi pada perangkat keras yaitu ditemuinya mesin tape reader yang bermasalah; b. Kembali lagi bahwa teknologi dalam inovasi adalah suatu barang atau perangkat yang di rangkai oleh manusia sehingga dalam penggunaannya tergantung pada optimalitas kondisi mesin yang prima; c. Hambatan lain yang peneliti jumpai adalah mengenai pola perilaku pedagang, ada pedagang yang support kebijakan eretribusi dan ada pula yang mengeluh bahkan ingin kembali ke metode konvensional mereka merasa kesulitan karena tidak dan kurang memahami masalah teknologi dan perbankan, sehingga mereka banyak yang mengatakan " lebih rumit 
karena harus ke bank, dan kesulitannya dalam penggunaan kartu".

\section{KESIMPULAN}

Program inovasi e-retribusi oleh Dinas Perdagangan Kota Surakarta mampu menyederhanakan pelayanan publik. E-retribusi membuat transparansi dan akuntabilitas sehingga para pedagang mendapatkan kejelasan pembayaran. b. E-retribusi dapat dikatakan belum berjalan sempurna, hal ini disebabkan oleh tingkat pendidikan pedagang yang rata-rata menengah ke bawah (rendah), sehingga beberapa pedagang belum mampu menggunakan inovasi e-retribusi, terlebih program e-retribusi adalah inovasi berbasis teknologi.

Adapun saran untuk meningkatkan inovasi pelayanan publik dalam program e-retribudi adalah : a. program e-retribusi perlu ditingkatkan pelaksanaannya. b. Pendampingan pada pedagang perlu dilakukan secara terus menerus, terlebih pada pedagang yang berpendidikan rendah. c. Dinas Perdagangan perlu untuk memberikan pendekatan secara psikologis kepada para pedagang dengan cara memantapkan para pedagang untuk ikut mendukung dan berpartisipasi.

\section{REFERENSI}

Estermann.,B. Riedl.,R. Neuroni,.A,C. 2009. "Integrated" And "Transcendent" E-government: Keys For Analyzing Organizational Structure and Governance. A Paper Published in the Proceedings of the 10th Annual International Conference on Digital Government Research. Bern University of
Applied Sciences. Competence Center Public Management and E-government.

Syamsuadi, Amir. 2017. Pelayanan

Publim dan Birokrasi

Pemerintahan. Prodi Ilmu

Pemerintahan Universitas

Abdurrab.

Ferryanto, Liem. 2009. Inovasi dan Strategi Pencapaiannya. Jurnal Teknik Industri

(JTI)

Vol.11.No.2.

Kabir. 2016. Pelayanan Publik Dalam Kerangka Otonomi Daerah. Papers Unisbank Semarang.

Kurniawan Agung. 2005. Transformasi Pelayanan Publik, Pembaharuan, Yogyakarta.

Kusumo, A.R. 2006. Analisis Faktorfaktor Yang Mempengaruhi INOVASI Produk Untuk Meningkatkan Keuanggulan Bersaing dan Kinerja Pemasaran (Studi pada Industri Batik Skala Besar dan Sedang di Pekalongan). Thesis UNDIP Semarang.

LAN. 2007. Dimensi Pelayanan Publik Dan Tantangannya Dalam Administrasi Negara (Publik) Di Indonesia. Jakarta: Bagian Humas dan publikasi

Lukas, B. \& Ferrel,O. 2000. The Effect of Market Orientation on Product Innovation. Journal of Academy of Marketing Science.

Muluk, Khairul. (2008). Knowledge Management Kunci Sukses Inovasi Pemerintah Daerah. Jatim: Bayumedia Publishing

Praswati, $\quad$ A.Nuryulia. 2017. Perkembangan Model Helix 
Dalam Meningkatkan Inovasi.

Prosiding SEMNAS Riset

Manajemen dan Bisnis. FEB

Universitas Muhammadiyah

Surakarta.

Rusli Budiman, 2013; Kebijakan Publik Membangun Pelayanan Publik yang Reponsif, Hakim

Publishimg, Bandung. 